\title{
Soft Tissue Sarcoma of the Abdomen and Thoracic Visceral Organs pT3 TNM Finding v8
}

National Cancer Institute

\section{Source}

National Cancer Institute. Soft Tissue Sarcoma of the Abdomen and Thoracic Visceral Organs pT3 TNM Finding v8. NCI Thesaurus. Code C136738.

Soft tissue sarcoma of the abdomen and thoracic visceral organs with tumor invading another organ. (from AJCC 8th Ed.) 